\title{
Efektivitas Penerapan Model Pembelajaran Kooperatif Quick on The Draw
}

\author{
Wayan Mahardika Prasetya Wiratama \\ mahardika.prasetya@undiksha.ac.id \\ Universitas Pendidikan Ganesha
}

\section{The Effectiveness of Application Cooperative Quick on The Draw Learning Models}

\begin{abstract}
This research is expected to provide an overview and information on the effectiveness of the 'Quick on the Draw' cooperative learning model implementation, so that it can be used as a reference material and develop it in a vocational high school study. This research is a classroom action research, aiming to improve the quality or solving problems occurring in a subject group that is researched and observed as a level of success or impact of his actions. The effectiveness of the model is assessed by student activity, student learning outcomes, and student response to the use of the model. The total score of the student activity observation is $87.5 \%$ $(85 \%<R A \leq 100 \%)$ in 'very active' category. The percentage of students that are collectively completed is $100 \%$, which means that the criteria for the effectiveness of learning devices are met. The interval of the student responses received from the average from student response poll became the class response, where the response of this class is at the range of $3.2(R \geq 3)$, meaning the average of overall response is positive and meet the criteria of the learning device effectiveness. The use of this learning model is expected to address the problems often faced by both teachers and students.
\end{abstract}

Keywords: Effectiveness, Cooperative Learning Model, Quick on The Draw

Received date: 19 Februari $2020 \quad$ Revised date: 5 Agustus 2020 Accepted date: 24 September 2020

\section{PENDAHULUAN}

Proses pembelajaran yang bermakna, sejatinya melibatkan siswa secara penuh dalam prosesnya. Agar siswa terlibat secara penuh di dalam proses pembelajaran, guru dituntut lebih kreatif dalam memilih serta menggunakan model pembelajaran. Proses pembelajaran yang bermakna nantinya akan menghasilkan siswa yang terampil dan berkualitas yang diharapkan dapat menciptakan perubahan di masyarakat, karena senjata bagi terciptanya perubahan adalah pendidikan dan pengetahuan yang bersumber dari guru itu sendiri.

Pembelajaran bermakna merupakan pembelajaran yang menggunakan model pembelajaran yang menjadikan siswa sebagai pusat dari proses belajar mengajar serta memberikan kesempatan sepenuhnya bagi siswa untuk mengeksplorasi kemampuannya. Hal tersebut akan menciptakan pengalaman belajar bagi siswa. Pengalaman belajar yang didapat siswa lebih mempunyai makna dan manfaat bagi kehidupannya jika dalam prosesnya siswa terlibat secara aktif.

Pembelajaran yang menyenangkan merupakan cerminan dari pembelajaran yang bermakna. Oleh sebab itu, guru memiliki peran yang sangat penting untuk memilih model pembelajaran yang dapat menghadirkan pembelajaran yang menyenangkan bagi siswa agar kelak siswa menjadi lulusan yang memiliki kualitas. Selain itu, permasalahan muncul dari siswa yang tidak terbiasa belajar mandiri. Siswa kurang berinisiatif mencari referensi seputar materi pembelajaran dan mempelajarinya, akan tetapi lebih memilih menunggu penjelasan dari guru. Hal ini berpotensi pada rendahnya aktivitas siswa dan berdampak pada rendahnya hasil belajar siswa.

Susanto (2012) berpendapat bahwa pembelajaran yang berpusat pada guru yang menyebabkan rendahnya aktivitas serta berdampak pada hasil belajar siswa. Sejalan dengan pendapat tersebut, Philip R Wallace yang dikutip dalam Sunarto (2009) menyatakan bahwa guru hanya mentransfer ilmu pengetahuan kepada siswa di dalam pembelajaran yang berpusat pada guru sedangkan siswa cenderung lebih banyak berperan sebagai penerima. Pembelajaran model tersebut biasa disebut dengan pembelajaran konvensional. 
Hal ini diungkapkan oleh Brooks yang dikutip dalam Warpala (2009) dimana Brooks menyatakan bahwa pembelajaran konvensional lebih menekankan kepada tujuan pembelajaran berupa penambahan pengetahuan, sehingga belajar dilihat sebagai proses "meniru" dan siswa dituntut untuk dapat mengungkapkan kembali pengetahuan yang sudah dipelajari melalui kuis atau tes. Dalam pembelajaran konvensional dikenal juga adanya belajar kelompok, namun memiliki perbedaan yang prinsipil dengan kerja kelompok dalam pembelajaran kooperatif diantaranya memfokuskan pada prestasi individu, dalam proses belajar hanya sedikit terjadi proses diskusi antar siswa, kemampuan sosial diabaikan, pembentukan kelompok diabaikan bahkan tidak ada, yang ada berupa kelompok besar yaitu kelas.

Sarnoko (2016) menekankan bahwa aktivitas belajar memiliki peran sangat penting dalam kegiatan pembelajaran karena dalam prosesnya, belajar dilakukan dengan mempraktekkan secara langsung (learning by doing). Oleh sebab itu, guna terlaksananya pembelajaran yang baik, harus menekankan pada aktivitas di dalam proses pembelajaran itu sendiri yang melibatkan siswa serta guru yang saling memiliki ketergantungan satu sama lainnya dan harus dilibatkan secara utuh untuk mencapai tujuan dari pendidikan. Dengan adanya masalah yang muncul seperti siswa yang kurang terbiasa belajar mandiri dan rendahnya aktivitas belajar siswa yang berpengaruh pada hasil belajar dimana muncul karena kurang tepatnya pemilihan model pembelajaran oleh guru, menunjukkan perlunya perbaikan pada proses pembelajaran yang menjadikan pembelajaran tidak lagi terpusat pada guru.

Berbagai model pembelajaran telah banyak dikembangkan, salah satu diantaranya adalah cooperative learning. Pembelajaran kooperatif berpusat kepada siswa dan melibatkan siswa secara langsung dalam proses belajar mengajar yang akan berdampak pada keaktifan siswa dalam proses pembelajaran. Pembelajaran kooperatif dilaksanakan dengan cara siswa membentuk kelompok kecil untuk mencapai tujuan bersama.

Gur (2013) menyatakan bahwa model pembelajaran kooperatif merupakan pembelajaran yang dalam prosesnya menuntut siswa saling membantu sesama rekan kelompoknya. Kerjasama yang baik antar rekan kelompok menyebabkan pembelajaran menjadi lebih kondusif, karena sejatinya pembagian kelompok terdiri lima sampai enam orang siswa dengan latar belakang berbeda atau heterogen. Selain itu, menurut Ebrahim (2012) hubungan sosial antar sesama rekan kelompok akan meningkat dengan menggunakan model pembelajaran kooperatif karena adanya saling ketergantungan sesama anggota kelompok untuk mencapai tujuan dari kelompoknya. Pembelajaran kooperatif meningkatkan kebersamaan serta tanggungjawab siswa di dalam kelompok (Martha, 2015).

Kerjasama dalam pembelajaran kooperatif akan dapat mengembangkan pengetahuan siswa yang menyebabkan siswa dapat berpikir kreatif, tidak tertutup dari penerimaan saran dari rekan kelompoknya dan mampu menyampaikan ide serta berdampak pada aktivitas siswa yang awalnya ditandai dengan kesiapan siswa memulai pembelajaran, kerjasama, keseriusan, dan keberanian siswa. Model pembelajaran kooperatif juga memberikan kesempatan yang lebih luas kepada siswa untuk memperoleh dan mengembangkan pengetahuan, sikap, nilai serta keterampilan yang nantinya bermanfaat bagi kehidupan siswa di masyarakat. Lebih ditekankan lagi bahwa dalam pembelajaran kooperatif, siswa bukan hanya menerima penjelasan dari guru, melainkan juga dapat belajar dari rekannya.

Pemerintah melalui Permendikbud No. 22 Tahun 2016 menjabarkan bahwa proses belajar mengajar yang dilakukan harus membuat siswa aktif, kreatif, dan inovatif agar bermakna bagi siswa sehingga siswa menemukan pengetahuan melalui kesan dari pengalaman belajar yang diperolehnya. Tindak lanjut dari permendikbud ini adalah pembaharuan kurikulum disetiap jenjang pendidikan. Dampak dari pembaharuan ini adalah masalah yang konkrit yang menjadi pekerjaan rumah untuk setiap pelaku di dunia pendidikan terutama subjek utama dalam pendidikan yaitu guru dan siswa. Semua mata pelajaran menuntut siswa untuk aktif kreatif dan inovatif dalam menggunakan pengetahuan dan dikembangkan untuk menemukan pemecahan masalah yang diinginkan.

Dari permasalahan mendasar tersebut, pertama kali yang harus dilakukan oleh guru adalah perubahan pola pikir. Pada prosesnya, guru dituntut untuk menggunakan pendekatan saintifik dan berperan lebih menjadi fasilitator dan motivator daripada inisiator dan eksekutor, sehingga memungkinkan siswa untuk terlibat aktif dalam pembelajaran melalui mengamati, menanya, menalar pada proses inquiry learning atau discovery learning dan dapat merubah dari teacher centered menjadi student centered. Akan tetapi, pada mata pelajaran dasar listrik dan elektronika khususnya pada materi 
daya dan energi listrik yang sebagian besar mengarah pada perhitungan, siswa akan mengalami kesulitan apabila mereka mengkonstruksi sendiri pengetahuan dengan pengalaman dan objek yang mereka amati, sampai mereka bisa membentuk jejaring (networking).

Perbedaan karakteristik siswa dan kesulitan belajarlah yang menuntut guru mencari model pembelajaran yang lain, agar mereka dalam proses belajar mereka dapat bekerja sama dalam menyelesaikan permasalahannya dengan menekankan interaksi sosial dengan orang-orang lain yang lebih punya pengetahuan lebih baik. Maka dari itu, implementasi cooperative learning akan membantu siswa bisa menyikapi keberagaman dan kerjasama sebagai etos akademik dalam menemukan dan mengungkap fenomena ilmiah, yakni dari kebiasaan anak diberi tahu mengarah kepada memfasilitasi anak mencari tahu. Sementara authentics assessment semakin dikedepankan sebagai assessment for learning dari pada assessment of learning.

Quick on the draw merupakan salah satu strategi dari pembelajarn kooperatif. Strategi quick on the draw diperkenalkan oleh Paul Ginnis (2008) yang menyatakan bahwa pada prosesnya setiap kelompok mencari dan menulis jawaban dari persoalan di sebuah kertas menggunakan materi sumber sebagai acuannya dan selanjutnya jawaban akan dibawa ke guru selanjutnya diperiksa. Tujuan utama dari pembelajaran ini adalah membiasakan siswa belajar pada sumber bukan pada guru. Kegiatan ini memberikan pengalaman yang didorong dengan kecepatan aktivitas, kecakapan, serta belajar mandiri untuk meningkatkan keterampilan membaca untuk menjawab sebuah persoalan dengan cepat, memilah materi yang penting untuk dipelajari, dan berhati-hati membaca pertanyaan.

Aktivitas dalam pembelajaran ini menekankan pada kerjasama, dimana efisiensi kerja kelompok akan berdampak pada kemajuan kelompok tersebut. Dalam kegiatan ini kelompok akan belajar bahwa membagi tugas dirasa lebih produktif dibandingkan dengan menduplikasi tugas (Ginnis, 2008:164). Model pembelajaran kooperatif quick on the draw akan menjadikan kondisi pembelajaran lebih menyenangkan karena dalam prosesnya diselimuti dengan suasana permainan. Model pembelajaran kooperatif quick on the draw memiliki fungsi yaitu team building (membangun tim), social skills (keterampilan sosial), thinking skills (keterampilan berpikir), communication skills (keterampilan berkomunikasi), processing info (mengelola info), dan knowledge building (membangun pengetahuan).

Sintak dalam model pembelajaran kooperatif quick on the draw diawali dengan: (1) menyipakan set pertanyaan, menganai topik yang sedang dibahas; (2) membagi kelas ke dalam kelompok dan memberi warna untuk setiap kelompok sesuai dengan warna dari kertas pertanyaan yang telah disusun; (3) memberi setiap kelompok handout yang di dalamnya terdapat penyelesaian untuk semua pertanyaan; (4) saat guru berkata "mulai" satu orang dari setiap kelompok lari ke depan untuk mengambil pertanyaan pertama; (5) kelompok mencari, menyelesaikan, dan menulis jawaban di kertas terpisah dipandu dengan handout; (6) membawa jawaban yang telah diselesaikan kepada guru dan guru memeriksa jawaban; (7) pertanyaan kedua dari tumpukan diambil jika jawaban dari pertanyaan sebelumnya sudah dinyatakn benar oleh guru; (8) siswa lainnya membaca handout dan membiasakan dengan isinya sehingga nanti dapat menjawab pertanyaan dengan lebih efisien; (9) pemenang diberikan kepada kelompok pertama yang menjawab semua pertanyaan dengan benar; dan (10) membahas semua pertanyaan yang sudah diberikan dan siswa membuat catatan tertulis.

Disimpulkan bahwa terdapat beberapa keterampilan sosial yang melekat pada pembelajaran quick on the draw antara lain adalah responsibility (tanggung jawab), sharing (berbagi), taking turns (bergantian), working together (bekerjasama), communication (komunikasi), tolerance (toleransi), providing clarification (memberikan klarifikasi), knowladge building (membangun pengetahuan), switching roles (beralih peran), problem solving (pemecahan masalah), procedur learning (proses belajar), staying on task (tetap pada tugas), praising (memuji), patience (kesabaran), thinking skills (keterampilan berpikir), offering help (menawarkan bantuan), following directions (mengikuti petunjuk), encouraging contribusi (saling berkontribusi), dan active listening (mendengarkan secara aktif).

Hasil penelitian tersebut mengisyaratkan penggunaan model pembelajaran kooperatif tipe quick on the draw dapat menjebatani keresahan mengenai masalah mutu dan esensi pembelajaran dalam upaya pencapaian tujuan dari pendidikan nasional. Kegiatan pembelajaran di SMK yang nantinya selain untuk mencapai tujuan dari pendidikan yang tersirat dalam kurikulum juga diarahkan pada usaha-usaha khusus yaitu pelibatan secara aktif terhadap siswa dalam kegiatan di kelas yang mana akan menjadikan siswa pusat dari kegiatan belajar mengajar. 
Dari latar belakang dan kajian literatur di atas, maka tujuan penulisan ini diharapkan dapat memberikan gambaran dan informasi mengenai efektivitas penerapan model pembelajaran kooperatif quick on the draw, sehingga dapat dijadikan bahan rujukan dan mengembangkannya dalam pembelajaran di sekolah menengah kejuruan.

\section{KAJIAN PUSTAKA}

\section{a) Pembelajaran Kooperatif Tipe Quick on The Draw}

Pembelajaran koopertaif tipe quick on the draw adalah sebuah kegiatan belajar mengajar yang mengutamakan pada aktivitas siswa dan kerjasama siswa dalam mencari, menjawab, serta melaporkan informasi dari berbagai sumber dalam suasana permainan. Selain itu, menurut Isjoni yang dikuti dalam Hapsari (2017) menyatakan bahwa pembelajaran kooperatif adalah pembelajaran yang menggunakan kelompok-kelompok kecil sehingga siswa-siswa saling bekerjasama untuk mencapai tujuan pembelajaran.

Pertama kali diperkenalkan oleh Ginnis (2008:163) yang menginginkan agar siswa dapat bekerja sama secara kooperatif dengan tujuan menjadi kelompok pertama yang menyelesaikan satu set pertanyaan. Suasana permainan di dalam prosesnya akan mejadi belajar mengajar di dalam kelas menjadi lebih menarik serta menimbulkan efek rekreatif pada proses belajar siswa karena dalam pembelajaran ini, siswa dirancang melakukan aktivitas yang menimbulkan saling ketergantungan, kecerdasan emosional, artikulasi, multi sensasi, fun, dan kemandirian. Oleh sebab itu, pembelajaran yang dapat memacu siswa berinteraksi dengan baik dengan siswa lainnya, dapat dilakukan guru dengan cara menerapkan model pembelajaran kooperatif (Suprijono dalam Kusumawati dan Mawardi, 2016).

Elemen yang didapat dalam aktivitas ini adalah bergerak, berbicara, membaca, kerja individu, kerja kelompok, melihat, menulis, dan mendengarkan. Meskipun di sekolah sekarang ini sudah diterapkan strategi pembelajaran yang inovatif, akan tetapi masih banyak guru dalam kegiatan belajar mengajar mengutamakan penggunaan pembelajaran konvensional tanpa didukung oleh cara atau model yang lebih efektif. Ha ini akan berdampak pada aktivitas siswa yang menjadi pasif dan menyebabkan siswa tidak bergairah serta merasa bosan saat mengikuti proses belajar mengajar. Gurulah yang berperan penting sebagai inspirator, motivator, mediator untuk memilih model pmebelajaran yang tepat sebagai pendamping dari pembelajaran konvensional dimana sejatinya penggunaan model pembelajaran bertujuan agar siswa aktif dalam proses pembelajaran. Dalam hal ini, model pembelajaran tipe quick on the draw adalah salah satu strategi yang tepat untuk digunakan dalam proses belajar mengajar agar membuat siswa menjadi aktif dan lebih bergairah di dalam prosesnya. Model pembelajaran ini menekankan aspek kerjasama kelompok untuk menjawab sebuah permasalahan dengan mencari informasi pada sumbernya dan selanjutnya melaporkan hasilnya dalam suasana permainan.

\section{b) Penilaian Hasil Belajar}

Hasil belajar merupakan suatu gambaran dari penugasan siswa terhadap kegiatan pembelajaran yang dilakukan guru. Hasil belajar merupakan suatu prestasi yang ingin dicapai siswa setelah mengikuti proses pembelajaran, sedangkan hakikat dari proses pembelajaran adalah terjadinya suatu proses yang dapat mengubah tingkah laku dalam diri siswa. Sehubungan dengan ini, Nana (2002:22) menyatakan bahwa hasil belajar merupakan kemampuan-kemampuan yang dimiliki siswa setelah ia menerima pengalaman belajar. Hasil belajar dapat diketahui melalui hasil test yang diberikan penilaian. Hasil belajar siswa digunakan untuk memotivasi siswa dan guru agar melakukan perbaikan dan peningkatan kualitas proses pembelajaran.

Permendiknas Nomor 41 Tahun 2007 tentang standar proses menyatakan bahwa penilaian dilakukan oleh guru terhadap hasil pembelajaran untuk mengukur tingkat pencapaian kompetensi siswa serta digunakan sebagai bahan penyusunan laporan kemajuan hasil belajar dan memperbaiki proses pembelajaran. Jadi, untuk mengukur tingkat keberhasilan siswa dalam pembelajaran dilakukan evaluasi atau penilaian hasil belajar. Berdasarkan pernyataan di atas, dapat disimpulkan bahwa hasil belajar merupakan tolak ukur keberhasilan seorang siswa mengikuti kegiatan belajar. Penilaian hasil belajar dilihat dari ranah kognitif, afektif dan psikomotor. Hasil belajar memiliki kemampuan yang di peroleh siswa setelah melalui kegiatan belajar dapat mencapai tujuan pembelajaran. Aspek yang penting dan mempengaruhi hasil belajar dalam keberhasilan pembelajaran adalah penguasaan 
model pembelajaran oleh guru (Son, 2019). Sebagaimana Bloom (dalam Arikunto, 2008:117-122) mengklasifikasikan hasil belajar menjadi tiga ranah kawasan, yaitu:

a. Ranah kognitif, yang meliputi pengetahuan, pemahaman, penerapan, analisis, sintesis, dan evaluasi.

b. Ranah afektif, mencakup penerimaan, partisipasi, penilaian, atau penentuan sikap, organisasi dan pembentukan pola hidup.

c. Ranah psikomotor, terdiri dari persepsi, kesiapan, gerakan terbimbing, gerakan terbiasa, gerakan kompleks dan penyesuaian pola gerakan dan kreativitas.

Ketiga ranah tersebut menjadi objek penilaian hasil belajar. Penilaian ranah kognitif dapat dilakukan dengan memberikan tes tertulis kepada siswa. Tes tertulis ini merupakan tes dimana soal dan jawaban yang diberikan kepada siswa dalam bentuk tulisan. Salah satu bentuk tes tertulis yaitu tes pilihan ganda yang dapat mengukur kemampumpuan berfikir siswa dengan cakupan materi yang lebih luas. Penyusunan instrumen pada tes tertulis harus memperhatikan beberapa hal yaitu keluasan ruang lingkup materi, kesesuaian soal dengan kompetensi dasar dan indikator yang akan dicapai, rumusan soal harus jelas (Mukhlis dan Tohir, 2019).

Penilaian ranah afektif atau dikenal dengan penilaian sikap dapat dilakukan dengan beberapa cara atau teknik, salah satu tekniknya yaitu observasi perilaku dengan menggunakan skala sikap. Skala sikap yang ditetapkan dapat berupa kode bilangan seperti misalnya untuk selalu diberi kode 5 , seringkali diberi kode 4, kadang-kadang diberi kode 3, jarang diberi kode 2, tidak pernah diberi kode 1 (Arikunto, 2008). Sikap yang akan dinilai yaitu berupa nilai-nilai karakter yang muncul selama proses pembelajaran yaitu kerja keras, kerja sama, ingin tahu, disiplin, tanggung jawab dan percaya diri. Sedangkan penilaian psikomotor digunakan untuk melihat keterampilan dan kemampuan bertindak siswa.

Penilaian psikomotor dilakukan dengan menggunakan kode angka 1 untuk tidak tepat, 2 kurang tepat dan 3 tepat. Penilaian psikomotor dilakukan pada saat pelaksanaan praktikum. Penilaian psikomotor ini dibagi menjadi 3 tahap yaitu: (1) tahap persiapan yang terdiri dari menyiapkan alat dan mengkalibrasi alat; (2) tahap pelaksanaan yang terdiri dari penggunaan alat dan pembacaan skala; dan (3) tahap hasil yang terdiri dari mengolah data dan menarik kesimpulan.

Sudjana (2002) juga mengatakan bahwa penilaian hasil belajar adalah proses pemberian nilai terhadap hasil-hasil belajar yang dicapai siswa dengan kriteria tertentu. Hal ini mengisyaratkan bahwa objek yang dinilainya adalah hasil belajar siswa. Hasil belajar siswa pada hakikatnya merupakan perubahan tingkah laku setelah melalui proses belajar mengajar. Tingkah laku sebagai hasil belajar dalam pengertian luas mencakup bidang kognitif, afektif dan psikomotor. Penilaian dan pengukuran hasil belajar dilakukan dengan menggunakan tes hasil belajar, terutama hasil belajar kognitif berkenaan dengan penguasaan bahan pengajaran sesuai dengan tujuan pendidikan dan pengajaran.

Hasil belajar merupakan hal yang dapat dipandang dari dua sisi yaitu sisi siswa dan dari sisi guru. Dari sisi siswa, hasil belajar merupakan tingkat perkembangan mental yang lebih baik bila dibandingkan pada saat sebelum belajar. Tingkat perkembangan mental tersebut terwujud pada jenisjenis ranah kognitif, afektif, dan psikomotor. Sedangkan dari sisi guru, hasil belajar merupakan saat terselesaikannya bahan pelajaran. Hasil juga bisa diartikan adalah bila seseorang telah belajar akan terjadi perubahan tingkah laku pada orang tersebut, misalnya dari tidak tahu menjadi tahu, dan dari tidak mengerti menjadi mengerti. Kurang aktifnya siswa pada saat mengikuti proses pembelajaran akan berpengaruh terhadap kemandirian siswa untuk dapat menemukan dan menyelesaikan berbagai masalah yang ditemui siswa pada saat proses pembelajaran, sehingga hal tersebut juga akan berpengaruh terhadap hasil belajar siswa Virgiantoro (2017).

Hasil belajar merupakan suatu puncak proses belajar. Hasil belajar tersebut terjadi terutama berkat evaluasi guru. Hasil belajar dapat berupa dampak pengajaran dan dampak pengiring. Kedua dampak tersebut bermanfaat bagi guru dan siswa. Hasil pengukuran belajar inilah akhirnya akan mengetahui seberapa jauh tujuan pendidikan dan pengajaran yang telah dicapai dari penjelasan beberapa ahli, dapat diambil kesimpulan bahwa belajar pada hakekatnya adalah proses perubahan perilaku siswa dalam bakat pengalaman dan pelatihan (Fatmaningrum, Sumadi, dan Haryono, 2015). Adapun tujuan penilaian hasil belajar yang diutarakan oleh Sudjana (2005) sebagai berikut.

a. Mendeskripsikan kecakapan belajar siswa sehingga dapat diketahui kelebihan dan kekurangannya dalam berbagai bidang studi atau mata pelajaran yang ditempuhnya. Dengan pendeskripsian kecakapan tersebut dapat diketahui pula posisi kemampuan siswa dibandingkan dengan siswa lainnya. 
b. Mengetahui keberhasilan proses pendidikan dan pengajaran di sekolah, yakni seberapa jauh keefektifannya dalam mengubah tingkah laku siswa ke arah tujuan pendidikan yang diharapkan.

c. Menentukan tindak lanjut hasil penilaian, yakni melakukan perbaikan dan penyempurnaan dalam hal program pendidikan dan pengajaran serta sistem pelaksanaan.

d. Memberikan pertanggungjawaban (accountability) dari pihak sekolah kepada pihak-pihak yang berkepentingan.

\section{METODE PENELITIAN}

Penelitian ini merupakan penelitian tindakan kelas (classroom action research), dimana berfokus pada penerapan tindakan dengan tujuan meningkatkan mutu atau memecahkan permasalahan yang sedang terjadi pada suatu kelompok subjek yang diteliti dan diamati tingkat keberhasilannya atau dampak dari tindakannya. Alasan penggunaan metode classroom action research karena penelitian tindakan memiliki dua tujuan, yaitu meningkatkan (improve) dan melibatkan (involve) dimana efektivitas penerapan model pembelajaran kooperatif quick on the draw dinilai dari aktivitas siswa, hasil belajar siswa dan respon siswa terhadap penggunaan model pembelajaran kooperatif quick on the draw.

Subjek penelitian ini adalah siswa di SMK Negeri 3 Singaraja. Data yang digunakan pada penelitian ini berupa data kuantitatif dan data kualitatif. Analisis pada data kuantitatif digunakan menganalisa data berupa skor dari hasil observasi aktifitas siswa, skor hasil belajar siswa dan respon siswa. Sedangkan analisis pada data kualitatif digunakan untuk menganalisa data berupa masukan, tanggapan, dan saran perbaikan berdasarkan hasil penilaian pada lembar observasi. Hasil data yang diperoleh akan dianalisis dengan cara deskriptif kualitatif yang meliputi reduksi data, penyajian data, serta penarikan kesimpulan.

\section{a) Aktivitas Siswa}

Instrumen penilaian berupa angket diberikan kepada guru untuk mengamati aktivitas siswa selama proses pembelajaran dengan menggunakan model pembelajaran kooperatif tipe quick on the draw. Data observasi dari observer akan dianalisis menggunakan rumus sebagai berikut.

Keterangan:

$$
S_{s}=\frac{S t}{S m} \times 100 \%
$$

$S_{S}:$ Persentase skor hasil observasi dari masing-masing observer

$S t$ : Skor total hasil observasi aktivitas siswa dari masing-masing observer

$\mathrm{Sm}$ : Skor maksimal yang dapat diperoleh dari hasil observasi aktivitas siswa

(Adaptasi dari Akbar, 2013)

Setelah persentase skor hasil observasi dari observer diperoleh, berikutnya menghitung skor rata-rata menggunakan rumus berikut.

Keterangan:

$$
P A=\frac{\sum_{o=1}^{d} S_{S}}{p}
$$

$P A$ : Persentase skor rata-rata hasil observasi gabungan pada setiap pertemuan

$S_{S}$ : Persentase hasil observasi dari observer ke-d

$d$ : Banyaknya observer

(Adaptasi dari Akbar, 2013)

Dari persentase skor rata-rata hasil observasi gabungan pada setiap pertemuan yang diperoleh akan dihitung persentase rata-rata untuk seluruh pertemuan. Persentase rata-rata untuk seluruh pertemuan dihitung menggunakan rumus berikut ini.

Keterangan:

$$
R A=\frac{\sum_{o=1}^{p} P A}{p}
$$

$R A$ : Persentase rata-rata hasil observasi gabungan untuk seluruh pertemuan

$P A:$ Persentase skor rata-rata hasil observasi gabungan ke-p

$P \quad$ : Banyaknya pertemuan

(Adaptasi dari Akbar, 2013) 
Kriteria standar untuk observasi aktivitas siswa dimana interval skor dan kriterianya disajikan pada tabel berikut ini.

\begin{tabular}{ll}
\multicolumn{2}{c}{ Tabel 1. Kriteria Standar Aktivitas Siswa } \\
\hline Interval & Kriteria Aktivitas Siswa \\
\hline $85 \%<\mathrm{RA} \leq 100 \%$ & Sangat aktif \\
$70 \%<\mathrm{RA} \leq 85 \%$ & Aktif \\
$55 \%<\mathrm{RA} \leq 70 \%$ & Cukup aktif \\
$40 \%<\mathrm{RA} \leq 55 \%$ & Kurang aktif \\
$25 \% \leq \mathrm{RA} \leq 40 \%$ & Tidak aktif \\
\hline \multicolumn{2}{l}{ Sumber: Adaptasi dari Arikunto $(2013)$}
\end{tabular}

Pada penelitian ini, kriteria keberhasilan yang ditetapkan untuk aktivitas siswa adalah persentase rata-rata minimal berada pada kategori aktif.

b) Hasil Belajar Siswa

Penilaian hasil belajar siswa secara individu dilakukan pada setiap pertemuan dan dinilai menggunakan pedoman skor (rubrik penilaian). Aspek yang diukur pada rubrik penilaian yaitu kognitif, afektif, dan psikomotor. Penghitungan hasil belajar siswa menggunakan rumus berikut.

Keterangan: $\mathrm{N}=$ nilai akhir

$$
N=\frac{\text { Skor perolehan }}{\text { Skor maksimal }} \times 100 \%
$$

(Adaptasi dari Akbar, 2013)

Setelah memperoleh hasil belajar siswa untuk perorangan pada setiap pertemuan, langkah berikutnya adalah menentukan rata-rata hasil belajar siswa pada seluruh pertemuan. Rata-rata hasil belajar siswa pada seluruh pertemuan dicari dengan rumus sebagai berikut.

Keterangan:

$$
N R=\frac{\sum_{o=1}^{p} N}{p} \times 100 \%
$$

$N R$ : Nilai rata-rata siswa pada seluruh pertemuan

$N$ : Nilai akhir yang diperoleh siswa pada tiap pertemuan

$p$ : Banyaknya pertemuan

(Adaptasi dari Akbar, 2013)

Kriteria ketuntasan belajar siswa secara perorangan yang ditetapkan yaitu siswa mampu mencapai nilai minimal 75. Langkah terakhir yang perlu dilakukan adalah mencari persentase ketuntasan belajar siswa secara klasikal. Untuk mendapatkan persentase ketuntasan belajar siswa secara klasikal digunakan rumus berikut.

Keterangan:

$$
P K=\frac{t}{n} \times 100 \%
$$

$P K$ : Persentase ketuntasan belajar secara klasikal

$t \quad$ : Banyaknya siswa yang mencapai nilai $\geq 75$

$n \quad$ : Banyaknya peserta

(Adaptasi dari Akbar, 2013)

Kriteria ketuntasan belajar siswa secara klasikal dikatakan tercapai apabila 75\% siswa mampu mencapai nilai minimal 75. Penentuan Kriteria Ketuntasan Minimal (KKM) didapat dengan jalan: (1) menghitung jumlah kompetensi dasar (KD) setiap mata pelajaran disetiap kelas; (2) menentukan kekuatan atau nilai untuk setiap aspek atau komponen sesuai dengan kemampuang masing-masing aspek seperti aspek kompleksitas, aspek sumber daya pendukung (sarana), dan aspek intake; (3) jumlah nilai setiap komponen selanjutnya dibagi tiga untuk menentukan KKM setiap kompetensi dasar; (4) jumlah seluruh KKM kompetensi dasar selanjutnya dibagi dengan jumlah kompetensi dasar untuk menentukan KKM mata pelajaran; dan (5) KKM setiap mata pelajaran pada setiap kelas tidak sama tergantung pada kompleksitas kompetensi dasar, daya dukung, dan potensi siswa. 


\section{c) Respon Siswa}

Setiap aksi yang dilakukan selama pembelajaran pasti akan menimbulkan reaksi yang berbeda pada tiap-tiap siswa. Sikap yang dapat muncul pada siswa yaitu menerima atau menolak. Jika menerima, maka respon siswa terhadap pembelajaran tersebut positif. Jika menolak, maka respon siswa terhadap pembelajaran tersebut negatif. Karena hanya ada dua kemungkinan sikap yang dapat muncul pada siswa, maka skor yang digunakan adalah dari rentang 1 sampai 4 dimana akan dibagi menjadi dua, yaitu: $1 \leq r<3$ dan $3 \leq r \leq 4$. Data ini akan dianalisis dengan mengadaptasi konsep yang dikembangkan oleh Parta (2009). Adapun langkah-langkah yang akan dilakukan untuk menganalisis data respon siswa, yaitu: (1) merekap skor seluruh item untuk setiap siswa; (2) menghitung skor rata-rata respon siswa untuk perorangan $\left(S_{r}\right)$; (3) menghitung skor rata-rata respon kelas ( $R$ ); dan (4) menyimpulkan mengenai respon siswa berdasarkan pada kriteria yang ditetapkan. Kriteria yang ditetapkan berdasarkan hasil rata-rata respon siswa untuk perorangan $\left(S_{r}\right)$ dapat dilihat pada Tabel 2 berikut.

Tabel 2. Kriteria Standar Skor Rata-rata Respon Siswa

\begin{tabular}{cc}
\hline Interval & Kriteria Respon \\
\hline $\bar{s}_{r} \geq 3$ & Respon positif \\
$\bar{s}_{r}<3$ & Respon negative \\
\hline
\end{tabular}

Sumber: Adaptasi dari Yupitawati (2017)

Sedangkan kriteria yang ditetapkan untuk skor rata-rata respon kelas $(R)$ dapat dilihat pada Tabel 3 berikut ini.

Tabel 3. Kriteria Standar Skor Rata-rata Respon Kelas

\begin{tabular}{cc}
\hline Interval & Kriteria Respon \\
\hline$R \geq 3$ & Respon positif \\
$R<3$ & Respon negative \\
\hline
\end{tabular}

Sumber: Adaptasi dari Yupitawati (2017)

Kriteria keberhasilan yang ditetapkan untuk respon siswa sehingga memenuhi indikator keefektifan yaitu apabila respon seluruh siswa (respon kelas) positif.

\section{HASIL PENELITIAN DAN PEMBAHASAN}

Ada tiga indikator yang digunakan untuk mengetahui tingkat keefektifan penggunaan model pembelajaran kooperatif quick on the draw pada penelitian ini yaitu aktivitas siswa, respon siswa, dan ketuntasan hasil belajar. Ketiga indikator tersebut akan dijabarkan sebagai berikut.

\section{a) Aktivitas Siswa}

Indikator pertama yang menjadi penentu keefektifan perangkat pembelajaran adalah aktivitas siswa. Hasil observasi ini tersaji pada Tabel 4 di bawah ini.

Tabel 4. Hasil Observasi Aktivitas Siswa

\begin{tabular}{ccc}
\hline Pertemuan & $P A$ & $R A$ \\
\hline I & 86.8 & \\
II & 88.7 & $87 \mathrm{a} .5$ \\
III & 86.8 & \\
IV & 87.5 & \\
\hline
\end{tabular}

Pada Tabel 4 diketahui persentase tiap pertemuan $(P A)$ dari pertemuan I sampai pertemuan IV secara berturut-turut adalah $86,8 \% ; 88.7 \% ; 86,8 \%$; dan $87,5 \%$. Dari seluruh pertemuan tersebut berada pada kategori sangat aktif. Tercapainya kategori sangat aktif pada seluruh pertemuan disebabkan oleh antusias siswa untuk mengikuti proses belajar mengajar dengan menggunakan model kooperatif tipe quick on the draw. Siswa juga sangat aktif belajar berkelompok dan mempresentasikan hasil kerja kelompok. Selain itu siswa juga mampu mengutarakan kesulitan yang dihadapi serta dapat membuat kesimpulan. Persentase rata-rata dari seluruh pertemuan $(R A)$ sebesar $87,5 \%$ dengan kategori sangat aktif. Sesuai dengan kriteria keberhasilan yang telah ditetapkan maka aktivitas siswa telah memenuhi syarat. 


\section{b) Hasil Belajar Siswa}

Indikator kedua yang juga menentukan keefektifan perangkat pembelajaran adalah ketuntasan hasil belajar siswa. Kriteria keberhasilan yang ditetapkan untuk indikator ini adalah apabila persentase rata-rata ketuntasan belajar siswa secara klasikal mencapai $75 \%$. Sedangkan siswa yang dinyatakan tuntas hasil belajarnya apabila siswa mendapat nilai minimal 75.

Jika hasil belajar siswa dianalisis untuk setiap pertemuan, maka siswa yang mendapat nilai minimal 75 pada pertemuan I dan IV sebanyak 31 siswa atau 100\%. Pada pertemuan II sebanyak 29 siswa atau $93,5 \%$, sedangkan pada pertemuan III hanya 80,6\% atau sebanyak 25 siswa yang mampu mendapatkan nilai minimal 75. Rendahnya hasil belajar siswa pada pertemuan II dan III terjadi karena rendahnya keterampilan siswa terutama pada saat memasuki perhitungan daya listrik dan konsumsi energi listrik. Selain itu, kurangnya ketelitian siswa membaca dan memahami isi dari sumber belajar menjadi penyebab rendahnya hasil belajar siswa. Hal ini erat kaitannya dengan minat siswa belajar, dimana hasil penelitian dari Nurhasanah dan Sobani (2016) menunjukkan bahwa minat belajar berpengaruh signifikan terhadap hasil belajar siswa.

Dari kriteria ketuntasan hasil belajar yang ditetapkan, rata-rata hasil belajar siswa untuk seluruh pertemuan telah mencapai nilai minimal 75 . Secara klasikal pada seluruh pertemuan diperoleh persentase rata-ratanya yaitu sebesar $100 \%$. Hal tersebut menunjukkan bahwa kriteria keberhasilan untuk indikator ini, baik secara perorangan maupun klasikal telah terpenuhi.

\section{c) Respon Siswa}

Angket respon siswa berfungsi mengetahui bagaimana respon siswa mengenai proses belajar mengajar yang telah dilaksanakan selama menggunakan model pembelajaran kooperatif quick on the draw. Angket diberikan pada akhir pertemuan dan data dari angket respon siswa merupakan indikator terakhir yang menentukan tingkat keefektifan penerapan model pembelajaran yang digunakan.

Dari hasil penelitian, terdapat empat siswa yang skor rata-ratanya kurang dari $3\left(\bar{s}_{r}<3\right)$ dan menurut kriteria standar untuk skor rata-rata respon siswa maka respon siswa adalah negatif. Walaupun terdapat siswa yang memberikan respon negatif, namun skor rata-rata respon kelas yang diperoleh adalah 3,2 ( $R \geq 3$ ) dan kriteria standar untuk skor rata-rata respon kelas berada pada kategori positif. Berdasarkan pada kriteria keefektifan yang ditetapkan maka respon siswa telah memenuhi syarat.

\section{SIMPULAN DAN SARAN}

Untuk menentukan kesimpulan mengenai penerapan model pembelajaran berdasarkan pada analisis data hasil uji coba lapangan yang telah dilaksanakan selama kegiatan, maka seluruh data hasil analisis dirangkum dalam Tabel 5 sebagai berikut.

Tabel 5. Rangkuman Hasil Analisis Data

\begin{tabular}{ccccc}
\hline Kriteria & Indikator & Hasil & Kategori & Simpulan \\
\hline \multirow{3}{*}{ Efektivitas } & Aktivitas siswa & $87,5 \%$ & Sangat Aktif & \\
\cline { 2 - 4 } & Hasil belajar & $100 \%$ & Tuntas & \multirow{2}{*}{ Efektif } \\
\cline { 2 - 4 } & Respon siswa & 3,2 & Positif & \\
\hline
\end{tabular}

Dari rangkuman hasil analisis yang tersaji pada Tabel 5 di atas, semua kriteria yang ditentukan telah memenuhi syarat. Dengan demikian, dapat disimpulkan bahwa model pembelajaran kooperatif quick on the draw pada penelitian ini efektif untuk diterapkan di sekolah menengah kejuruan.

Uji Keefektifan model pembelajaran berdasarkan pada tiga kriteria yaitu aktivitas siswa, ketuntasan belajar klasikal dan respon siswa. Persentase skor total hasil observasi aktivitas siswa 87,5\% $(85 \%<\mathrm{RA} \leq 100 \%)$ berada pada kategori sangat aktif. Persentase siswa yang dinyatakan tuntas secara klasikal adalah sebesar $100 \%$ artinya kriteria efektivitas perangkat pembelajaran terpenuhi. Interval hasil respon siswa yang diperoleh dari angket respon siswa dirata-ratakan yang nantinya akan menjadi respon kelas, dimana respon kelas ini berada pada kisaran $3,2(\overline{\mathrm{R}} \geq 3)$, artinya rata-rata respon keseluruhan adalah positif dan memenuhi kriteria efektivitas perangkat pembelajaran.

Penggunaan model pembelajaran ini dapat membantu mengatasi masalah yang sering dihadapi oleh guru maupun siswa. Perangkat pembelajaran yang dikembangkan memungkinkan siswa terlibat secara penuh dalam proses pembelajaran. Sehingga, siswa mampu mengonstruksi sendiri pengetahuannya untuk memahami konsep yang tengah dipelajari dari sumber yang ada. Siswa dilatih 
untuk bekerjasama dengan cara berpasangan, sehingga secara bersama-sama siswa akan memahami materi yang tengah dipelajari. Dengan begitu, siswa memiliki kesempatan untuk berbagi setidaknya dengan satu siswa lainnya tentang pemikiran atau ide-ide sehingga dapat meningkatkan keterlibatan siswa di dalam kelas (Kagan, 2009).

Kegiatan pembelajaran ini juga merancang siswa untuk melakukan aktivitas seperti kecerdasan emosional, artikulasi, saling ketergantungan, fun, multi sensasi, kemandirian, dan berpikir. Elemen yang didapat dalam kegiatan ini adalah melihat, menulis, mendengarkan, berbicara, membaca, bergerak, dan bekerjasama. Hasil terakhir yang ingin ditunjukkan dari proses pembelajaran ini adalah siswa yang mampu bekerja bersama dalam sebuah kelompok dengan tujuan yang sama antar anggotanya untuk menjadi kelompok pertama yang menyelesaikan satu set pertanyaan. Pembelajaran akan menimbulkan efek rekreatif dan menjadi menarik bagi siswa dikarenakan proses pembelajaran bernuansa permainan (Ginnis, 2008:163).

Produk yang dikembangkan ini memiliki kelebihan dan kekurangan dimana didapat berdasarlan catatan yang diperoleh pada saat uji coba lapangan. Adapun kelebihan dari perangkat pembelajaran ini antara lain:

1. Kegiatan pembelajaran dirancang secara sistematis sesuai model yang digunakan sehingga kegiatan berjalan seperti perencanaan sebelumnya.

2. Aktivitas yang ada pada perangkat pembelajaran menjadikan siswa aktif dan terlibat secara utuh dalam proses belajar mengajar sehingga tidak ada lagi siswa yang diam dan hanya melihat saja.

3. Perangkat pembelajaran dengan menggunakan model ini dapat menumbuhkan interaksi antar siswa dalam satu kelompok serta antara siswa dan guru.

Sedangkan kelemahannya yaitu penggunaan alokasi waktu yang harus diperhatikan dan diperhitungkan dengan baik sehingga proses pembelajaran berjalan lancar dan sesuai rencana serta pengaturan kelas sangat penting dilakukan agar kelas tidak menjadi gaduh karena model pembelajaran ini menyesuaikan dengan karakter kinestik siswa yang tidak dapat duduk diam.

Berdasarkan hasil uji coba lapangan, saran-saran yang dapat diberikan agar penerapan model pembelajaran ini dapat optimal yaitu sebagai berikut.

1. Model pembelajaran ini dapat digunakan sebagai alternatif pembelajaran untuk sekolah yang memiliki masalah yang sama.

2. Bagi guru yang akan menerapkan model pembelajaran ini, hendaknya untuk memperhatikan alokasi waktu dan jumlah siswa, mengingat proses pembelajaran ini memerlukan banyak waktu untuk siswa mengonstruksi pemahamannya dan berbagi kepada teman kelompoknya.

3. Bagi Peneliti yang akan mengembangkan model pembelajaran ini, hendaknya pengembangan berada pada perangkat pembelajaran berupa handout dapat dikembangkan untuk digunakan sebagai sumber belajar siswa ketika pembelajaran dilaksanakan dengan model pembelajaran kooperatif quick on the draw dimana siswa dilatih untuk mandiri ketika mengerjakan soal serta bisa berbagi ide kepada siswa lainnya.

\section{DAFTAR PUSTAKA}

Akbar, S. 2013. Instrumen Perangkat Pembelajaran. Bandung: PT. Remaja Rosdakarya.

Arikunto, S. 2013. Manajemen Penelitian Edisi 12. Jakarta: PT. Rineka Cipta.

Fatmaningrum, S.A., Sumadi., Haryono, E. 2015. Pengaruh Penggunaan Model Pembelajaran Kooperatif Tipe Quick On The Draw Terhadap Hasil Belajar Siswa. Jurnal Penelitian Geografi, 3 (5). Retrieved from http://jurnal.fkip.unila.ac.id/index.php/JPG/article/ view/10159, diakses 28 Juli 2020.

Ginnis, P. 2008. Trik \& Taktik Mengajar Strategi Meningkatkan Pencapaian Pengajaran di Kelas. Jakarta: PT. Indeks.

Gur, C. 2013. Cooperative Learning in The Context of Early Childhood Education. International Journal of Arts and Education.

Hapsari, A.E. 2017. Penerapan Model Pembelajaran Kooperatif Tipe Numbered Heads Together Berbantuan Media Interaktif untuk Meningkatkan Aktivitas dan Prestasi Belajar Siswa. 
Scholaria: Jurnal Pendidikan dan Kebudayaan, 7 (1), 1-9. Retrieved from https://ejournal.uksw.edu/scholaria/article/view/707/471, diakses 28 Juli 2020.

Kagan, S. \& Kagan, M. 2009. Kagan Cooperative Learning. San Clemente, CA: Kagan Publishing.

Kemendikbud. 2016. Permendikbud Nomor 22 Tahun 2016 Tentang Standar Proses Pendidikan Dan Menengah. Jakarta: Kemendikbud.

Kusumawati, H., \& Mawardi. 2016. Perbedaan Penerapan Model Pembelajaran Kooperatif Tipe NHT dan STAD Ditinjau dari Hasil Belajar Siswa. Scholaria: Jurnal Pendidikan dan Kebudayaan, 6 (3), 251-263. Retrieved from https://ejournal.uksw.edu/scholaria/ article/view/707/471, diakses 28 Juli 2020.

Martha, J.A. 2015. Peningkatan Hasil Belajar, Aktivitas, dan Efikasi Diri melalui Pembelajaran Model Carosoul Feedback dan Showdown pada Mata Pelajaran Kewirausahaan. Jurnal Konseling Indonesia, http;//ejournal.unikama.ac.id, diakses 15 Januari 2019.

Mukhlis, M., \& Tohir, M. 2019. Instrumen Pengukur Creativity And Innovation Skills Siswa Sekolah Menengah di Era Revolusi Industri 4.0. Indonesian Journal of Mathematics and Natural Science Education, 1(1), $65 \quad$ - $73 . \quad$ Retrieved from https://mass.iainjember.ac.id/index.php/mass/article/view/1, diakses 28 Juli 2020.

Nurhasabah, S., \& Sobandi, A. 2016. Minat Belajar Sebagai Determinan Hasil Belajar Siswa. Jurnal Pendidikan Manajemen Perkantoran, 1 (1), 128-135. Retrieved https://ejournal.upi.edu/ index.php/jpmanper/article/view/3264/2338, diakses 28 Juli 2020.

Sarnoko, R \& Punadji, S. 2016. Penerapan Pendekatan SAVI Berbantuan Video Pembelajaran untuk Meningkatkan Aktivitas dan Hasil Belajar IPS Siswa Kelas IV SDN I Sanan Girimarto Wonogiri. Jurnal Pendidikan: Teori, Penelitian, dan Pengembangan, http://journal.um.ac.id /index.php/jptpp/article/view/6524/2785), diakses 10 Maret 2019.

Son, R. S. S. (2019). Pengaruh Model Pembelajaran Kooperatif Tipe Time Token Terhadap Hasil Belajar Siswa SMP. Scholaria: Jurnal Pendidikan dan Kebudayaan, 9(3), 284-291.

Susanto, J. 2012. Pengembangan Perangkat Pembelajaran Berbasis Lesson Study dengan Kooperatif Tipe Numbered Head Together untuk Meningkatkan Aktivitas dan Hasil Belajar IPA di SD. Journal of Primary Educational, http://journal.unnes.ac.id/sju/index.php/jpe, diakses 10 Maret 2019.

Virgiantoro, E.V. 2017. Efektifitas Model Pembelajaran Kooperatif Learning Tipe Quick On The Draw Untuk Meningkatkan Kemandirian Dan Hasil Belajar Siswa Kelas X Pada Mata Pelajaran Ekonomi Di Sma N 1 Tempel Tahun Ajaran 2015/2016. Jurnal Pendidikan dan Ekonomi, 6 (3), 259-266. Retrieved from http://journal. student. uny.ac.id/ojs/ojs/ index.php/ekonomi/article/view/7151, diakses 28 Juli 2020.

Warpala, I.W.S. 2009. Pendekatan pembelajaran Konvensional, http://edukasi.kompasiana.com /2009/12/20/pendekatan-pembelajarankonvensional, diakses 28 Juli 2019.

Yupitawati, S. 2017. Pengembangan Perangkat Pembelajaran Bercirikan Model Pembelajaran 1Kooperatif Tipe Pairs Check Pada Materi Bilangan Bulat. Tesis: Universitas Negeri Malang. 